\title{
Raw Materials as a Driver of Economic Growth and Job Creation in the Transition to an Innovation-driven Low-carbon and Circular Economy
}

\author{
Peter Moser and Susanne Feiel \\ Resources Innovation Center Leoben, Montanuniversität Leoben, Leoben, Austria \\ Received January 28, 2019; accepted February 3, 2019; published online February 19, 2019
}

\begin{abstract}
This text was presented as a "Lunch Speech" at the High Level Working Group on Competitiveness and Growth, April 26th 2018, Brussels. It adresses the role of Raw Materials for a future Innovation-driven Low-carbon Circular Economy.
\end{abstract}

Keywords: Raw materials, Low-carbon circular economy, Innovation, Competitiveness, Economic growth

Rohstoffe als Treiber von Wirtschaftswachstum und Schaffung von Arbeitsplätzen im Rahmen des Wandels der Wirtschaft in Richtung einer Innovations-getriebenen, $\mathrm{CO}_{2}$ reduzierten Kreislaufwirtschaft

Zusammenfassung: Dieser Text basiert auf einem Vortrag, gehalten im Rahmen eines Treffens der Arbeitsgruppe Wettbewerb und Wachstum der Europäischen Generaldirektion für Binnenmarkt, Industrie, Unternehmertum und KMs. Der Vortrag spricht die Bedeutung von Rohstoffen für eine zukünftige Innovations-getriebene $\mathrm{CO}_{2}$ reduzierte Kreislaufwirtschaft an.

Schlüsselwörter: Rohstoffe, $\mathrm{CO}_{2}$ reduzierte Kreislaufwirtschaft, Innovation, Wettbewerb, Wachstum

\section{Opening}

As contribution to a debate on the industrial future in Europe on job creation and innovation-driven growth the following questions need to be raised:

Text presented as "Lunch Speech" at High Level Working Group on Competitiveness and Growth, April 26th 2018, Brussels.

Univ.-Prof. Dipl.-Ing. Dr. mont. P. Moser (四)

Resources Innovation Center Leoben,

Montanuniversität Leoben,

Franz Josef-Str. 18,

8700 Leoben, Austria

peter.moser@unileoben.ac.at
- Do we really need Mineral Raw Materials from European Sources for our industrial future?

- OR:

- Should we better let others produce the billion tons of mineral raw materials needed every year by industrial production in Europe, which is the basis of all EU value markets?

- Should we thus outsource the "responsibility for sustainability" of our product base although sustainability is very high on the political agenda?

- Should we become $100 \%$ dependent on global trade of which we cannot foresee the future and really eliminate the last part of domestic European mineral raw materials production?

- Should we really focus our strategy on $100 \%$ imports instead of aiming towards a sustainable supply from European sources-the potential for mineral raw materials production in Europe is there!

Let me throw now a very technocratic, non-emotional view on these issues, addressing the following four topics:

- Mineral raw materials-an indispensable basis for the circular economy approach

- Mineral raw materials-an indispensable basis for future low-carbon technologies

- Mineral raw materials-from European sources as part of a risk mitigation strategy

- Mineral raw materials - a part of a complex innovation biotope

\section{Mineral Raw Materials: The Indispensable Basis for Circular Economy}

In the concept of circular economy, we aim to supply our society more and more with raw materials from secondary deposits: recycled materials and waste. 
This approach is visionary; however, feasible only up to a certain extent as a number of societal factors, the laws of physics and especially thermodynamics impose limits as follows:

- Modern and developing societies have an enormous amount of raw materials stored as "in-stock use". This creates a delay of up to 100 years for different materials before they are available for recycling. Today's low recycling rates are not an expression of our lacking will for recycling but a consequence of the rather long use of materials as well as the increasing overall consumption of products and services.

- Recycling and extraction of substances from waste requires energy, which increases with the percentage of recovery in an exponential way. If the extraction percentage is above a certain value then this results in the need for an enormous amount of additional energy. The production of this energy would require more raw materials than we extract from the waste.

- The recycling of raw materials from waste often produces fresh material slightly or very different from primary raw materials, not due to improper recycling technologies but because the laws of physics set natural limits. Following the circular economy concept, it is necessary, however, to merge the two raw material flow streams to provide raw materials sustainably with the needed qualities for the emerging technologies.

\section{Mineral Raw Materials: An Indispensable Basis for Future Low-carbon Technologies}

Not everybody shares the same opinion on what the key enabling technologies of the future will be. However, the following three items can be agreed upon:

- Key technologies will be different in the future

- Future key technologies most likely will be built from a varying composition of numerous types of raw materials

- Technological change is a continuing trend

Raw materials cycles will therefore continue to change and the challenge is to create new sustainable raw materials cycles constantly. At the beginning of a new technology raw materials production from primary resources is necessary before secondary recycled material may serve as an additional source, like with the various new types of raw materials we need for low-carbon energy supply systems and for the batteries of the E-mobility in the future.

Even with the visionary concept of the low-carbon, circular economy the supply from primary resources is needed.

The good news is that these primary resources are available in European deposits.

\section{Raw Materials: From European Sources as Part of a Risk Mitigation Strategy}

According to expert analyses concerning the importance and the origin of raw materials for future-enabling technologies and their significance for European industry, a list of Critical Raw Materials was compiled: today 27 materials are critical in terms of economic importance and security of supply for our industry. 12 of these 27 materials are imported to $100 \%$ from supplier countries, many of which are politically unstable and have working standards far below European values. For all of the critical raw materials European import dependence is around $80 \%$.

The key to sustainability and a stable industrial base is resilience against all challenges. In the light of our inability to predict global trade conditions in terms of availability and pricing, we cannot give up on producing our own raw materials. We must even increase the production to ensure a stable innovation basis, a stable industrial basis, a stable economic basis, a stable market with stable prices to avoid strategic and thereby political dependency.

\section{Raw Materials: A Part of a Complex Innovation Biotope}

Raw Materials are part of innovation biotopes. What are the ingredients for such a biotope: brilliant people, affordable energy and integration along the value chain!

Integration along the value chain is what concerns us here today. It encompasses the concept that all production steps of a product are integrated in a region:

- the value chain, which consists of the extraction and provision of the needed raw materials,

- the development chain in which materials and products are being designed

- the production chain where products are finally realized.

The development chain is constantly designing new, better and more sustainable products. It needs the value chains and the productions chains to be ready to supply and produce when new products are underway. The timeline for innovation unfortunately does not match the speed of the value chain. Extracting a primary raw material, or finding the adequate technology to recycle materials with the correct material properties takes many years after first demands arise, as is the situation for batteries and E-cars today.

This can lead to precarious economic scenarios. Our economy must have all these steps integrated in one place to be stable and have specialists in politics that understand these mechanisms, so policy for specialized, strong and emerging markets can react accordingly. 


\section{Conclusions}

Considering all of the above, are there opportunities for a change?

The clear answer is "Yes".

1. Europe has the mineral potential to supply itself largely in crucial industries. However, today's exploration extends hardly beyond a depth of $300 \mathrm{~m}$, while mining down to $3000 \mathrm{~m}$ is feasible. Europe's ground must be explored by the brilliant geological surveys and its mineral raw materials potential made known to domestic innovation supply.

2. Policy and legislation play a significant role in the facilitation of mining and recycling practices. A unification process across the EU needs to be started to ensure investment security, easy value chain management and speedy permitting processes.

3. Societal acceptance of mineral raw materials production in Europe is a further crucial factor. But think about this: $98 \%$ of European construction raw materials (around 4 billion tons) are produced every year locally due to pric- ing and environmental issues. Polls show that people who live close to these production sites largely accept them. Personal connection to the extraction is comprehended and local benefit appreciated. This is a strong indicator that with the appropriate measures such an acceptance level can also be achieved for critical raw materials, metals and other mining projects.

Efforts must be joined to create framework conditions for an increased successful raw materials production from European sources for European products and society. Made in Europe-from bean to bar, according to the slogan of an Austrian chocolate producer.

Funding. Open access funding provided by Montanuniversität Leoben.

Open Access This article is distributed under the terms of the Creative Commons Attribution 4.0 International License (http://creativecommons. org/licenses/by/4.0/), which permits unrestricted use, distribution, and reproduction in any medium, provided you give appropriate credit to the original author(s) and the source, provide a link to the Creative Commons license, and indicate if changes were made. 